\title{
Effect of Mint Leaves with or without Enzyme Supplementation on Blood Biochemistry, Carcass Characteristics and Sensory Attributes of Broiler Chicken
}

\author{
A. Khursheed ${ }^{1}$, M.T. Banday ${ }^{1}$, A.A. Khan ${ }^{1}$, S. Adil ${ }^{*}$, A.M. Ganai ${ }^{2}$, I.U. SheikH ${ }^{1}$, A.H. Sofi ${ }^{3}$ \\ ${ }^{1}$ Department of Livestock Production and Management; ${ }^{2}$ Department of Animal Nutrition; ${ }^{3}$ Department of Live- \\ stock Products Technology, Faculty of Veterinary Sciences and Animal Husbandry, Sher-e-Kashmir University of \\ Agricultural Sciences and Technology of Kashmir, Shuhama, Srinagar-190006, India
}

\begin{abstract}
A study was conducted to evaluate the effect of dietary supplementation of Mint leaves (Mentha piperita) with or without enzyme treatment on blood chemistry, carcass characteristics and sensory attributes of broiler chicken production. 225 day old commercial broiler chicks reared together until 7 days of age. On 8 th day, the chicks were individually weighed, distributed randomly into 5 treatment groups of 3 replicates with 15 chicks each for a period of 42 days of age. Birds in the control group (T1) were fed diets without additives, whereas in T2 and T3 basal diet was supplemented with raw mint leaves@1\%(T2) and 2\% (T3). In T4 and T5, enzyme treated mint leaves@ 1\% and $2 \%$ were added to the basal diet respectively. At the end of experimental period, blood biochemistry, carcass characteristics and sensory attributes were recorded. The results revealed that there was no significant $(\mathrm{P}>0.05)$ effect on serum glucose, total protein, cholesterol, SGPT and SGOT levels of birds fed diets either supplemented with raw or enzyme treated mint leaves both at 1 and $2 \%$ levels when compared with the group of birds fed control diet. Further, various carcass characteristics viz. feather loss, evisceration loss, giblets, shank, head and dressing \% in the groups fed raw or enzyme treated 1 and $2 \%$ mint leaves showed a non significant $(\mathrm{P}>0.05)$ difference compared to control group. Moreover, no effect $(\mathrm{P}>0.05)$ on various sensory attributes and the overall acceptability of meat among the various treatment groups and control group was observed. In conclusion, the dietary inclusion of raw or enzyme treated mint leaves had no negative effect on the health of birds as could be figured out from the normal SGPT and SGOT levels of birds.
\end{abstract}

Keywords | Broiler chicken, Blood biochemistry, Carcass characteristics, Mentha piperita, Sensory attributes

Editor | Kuldeep Dhama, Indian Veterinary Research Institute, Uttar Pradesh, India.

Received | August 12, 2017; Accepted | August 27, 2017; Published | October 16, 2017

*Correspondence $\mid$ S. Adil, Department of Livestock Production and Management, Faculty of Veterinary Sciences and Animal Husbandry, SKUAST-K, Shuhama, Srinagar-190006, India; Email: aadilsheikh5@gmail.com

Citation | Khursheed A, Banday MT, Khan AA, Adil S, Ganai AM, Sheikh IU, Sofi AH (2017). Effect of mint leaves with or without enzyme supplementation on blood biochemistry, carcass characteristics and sensory attributes of broiler chicken. Adv. Anim. Vet. Sci. 5(11): 449-455.

DOI | http://dx.doi.org/10.17582/journal.aavs/2017/5.11.449.455

ISSN (Online) | 2307-8316; ISSN (Print) | 2309-3331

Copyright (C) 2017 Khursheed et al. This is an open access article distributed under the Creative Commons Attribution License, which permits unrestricted use, distribution, and reproduction in any medium, provided the original work is properly cited.

\section{INTRODUCTION}

The unfavourable effect of chemical products especially antibiotics led to the use of natural products like phytogenics to improve the efficiency of feed utilization and growth performance of poultry (Adil et al., 2015). The use of phytogenics as feed additives is gaining importance due to their antimicrobial and stimulatory effects on digestive system (Jamroz et al., 2003; Jang et al., 2004). They include herbs, spices or plants that are used to keep the gut microflora of poultry normal, which is a prerequisite for cost efficient and ecofriendly poultry production (Windisch and Kroismayr, 2006). It has been estimated that there are 250,000-500,000 species of plants on earth (Borris, 1996). Relatively, a small percentage (1-10\%) of these is used as food by both humans and other animal species (Cowan, 1999). Compared with synthetic antibiotics or inorganic chemicals, these plants and their derived products have re- 
ported to be less toxic, residue free and thus considered as ideal feed additives in animal production (Hashemi and Davoodi, 2010). These herbal plants exert positive effects on growth and health of animals probably by their immuno stimulatory properties (Guo et al., 2004).

Kashmir often referred to as paradise on earth is located at the north western tip of Himalayan biodiversity hotspot (Hussian, 2001). The region has a number of phytobiotics which may have the potential to promote production performance in chicken; and one amongst them being Mint (Mentha piperita), locally known as Pudina. Mint is a member of the Labiatae family and is widely used in herbal medicine and believed to be beneficial in as immunity enhancer (Nanekarani et al., 2012). Mint is mostly consumed after a meal because of its ability to reduce indigestion and intestinal spasms by reducing the gastrocholic reflux (Spirling and Daniels, 2001). The main action of its leaves and flowers is due to the presence of abundant menthol which is the main phenolic component having antibacterial activities (Schuhmacher et al., 2003). Mint also contains polyphenolic compounds and hence could possess strong antioxidant properties (Dorman et al., 2003). Further, the supplementation of enzyme in poultry diets has been reported to improve the performance (Yousuf et al., 2012) by degrading non-starchy polysaccharides and improving their digestion; having beneficial effect on gut morphology and thus improving absorption of nutrients (Tufarelli et al., 2007; Yousuf et al., 2011; Qureshi et al., 2016a). In view of such beneficial effects of mint and enzyme, a study was conducted to evaluate the efficiency of mint leaves, with or without enzyme supplementation on blood biochemistry, carcass characteristics and sensory attributes of broiler chicken.

\section{MATERIALS AND METHODS}

\section{ExPERIMENTAL Site}

The study was conducted in the Teaching and Research Farm of the Division of Livestock Production and Management, Faculty of Veterinary Sciences and Animal Husbandry, Sher-e-Kashmir University of Agricultural Sciences and Technology of Kashmir, Shuhama.

\section{Collection and Analysis of Test Material}

The locally available Mint leaves (Mentha piperita) were procured from the market. The material was dried and stored properly for future use. Dried samples of herb were subjected to proximate analysis as per the standard procedures.

\section{Experimental Diets and Treatment Groups}

The feeding programme consisted of a starter diet fed until 21 days and a finisher diet afterwards up to 42 days of age. Birds in the control group were fed the diets without any additive. The diets were formulated to meet the recommendations of Bureau of Indian standards (BIS, 2000). The ingredient and nutrient composition of the control diet is given in Table 1 . All the diets were prepared with the same batch of ingredients and all diets within a period had the same composition. The chicks were procured from a reputed source and reared together until 7 days of age. On 8th day, the chicks were individually weighed, distributed randomly into 5 treatment groups of 3 replicates with 15 chicks each. Birds in the control group (T1) were fed diets without additives, whereas in T2 and T3 basal diet was supplemented with raw mint leaves@ @ 1\% (T2) and 2\% (T3).In T4 and T5, enzyme treated mint leaves @ 1\% and $2 \%$ were added to the basal diet respectively. Enzyme used was a cocktail product added to the feed @ 50g per 100 $\mathrm{kg}$ of feed. Composition of Enzyme used was as follows: Cellulase 180000000, Amylase 125000, Xylanase 1800000, Phytase 200000, Protease 16000, Lipase 40000 and Pectinase $7000 \mathrm{IU} / \mathrm{g}$. Birds had ad libitum access to feed and water throughout and were maintained on a constant 24 hours light schedule. All chicks were vaccinated against Ranikhet disease on $5^{\text {th }}$ day with $\mathrm{F}_{1}$ strain vaccine and $\mathrm{B}_{2} \mathrm{~K}$ vaccine against Infectious bursal disease on $16^{\text {th }}$ day. All chicks were kept under the same managerial, hygienic and environmental conditions.

Table 1: Percent ingredient and nutrient composition of experimental basal diets (Dry matter basis)

\begin{tabular}{|c|c|c|}
\hline \multirow[t]{2}{*}{ Ingredients } & \multicolumn{2}{|l|}{ Diet } \\
\hline & $\begin{array}{l}\text { Starter } \\
(1-3 \text { weeks })\end{array}$ & $\begin{array}{l}\text { Finisher } \\
\left(4^{\text {th }} \text { and } 5^{\text {th }} \text { week }\right)\end{array}$ \\
\hline Yellow maize & 58.0 & 64.0 \\
\hline Soyabean meal & 38.0 & 32.0 \\
\hline Vegetable oil & 0.5 & 0.5 \\
\hline Premix* & 3.0 & 3.0 \\
\hline Salt $(\mathrm{NaCl})$ & 0.3 & 0.3 \\
\hline Methionine & 0.1 & 0.1 \\
\hline Lysine & 0.1 & 0.1 \\
\hline Total & 100 & 100 \\
\hline \multicolumn{3}{|l|}{ Calculated values } \\
\hline $\begin{array}{l}\text { Metabolizable energy } \\
\text { (Kcal/kg/diet) }\end{array}$ & 2850 & 2900 \\
\hline Crude protein (\%) & 22.4 & 20.2 \\
\hline Calcium & 1.13 & 1.23 \\
\hline Available phosphorus & 0.57 & 0.63 \\
\hline Methionine + Cystine & 0.80 & 0.75 \\
\hline \multicolumn{3}{|c|}{$\begin{array}{l}\text { *Premix contained: Provided per kg of diet. Vitamin A, } 1400 \mathrm{IU} \text {; } \\
\text { Vitamin D } 300 \mathrm{IU} \text {; Vitamin E, } 50 \mathrm{mg} \text {; Vitamin K,4 g; Vitamin } \\
\mathrm{B}_{6} 3 \mathrm{mg} \text {; Vitamin } \mathrm{B}_{12} 6 \mathrm{mg} \text {; Niacin, } 60 \mathrm{mg} \text {; Pantothenic acid } 20 \\
\text { mg; Folic acid } 0.2 \mathrm{mg} \text {; Choline } 150 \mathrm{mg} \text {; Ca,4.8 mg; P,3.18 mg; } \\
\text { Mn,100 mg; Fe, } 50 \mathrm{mg} \text {; Zn, } 80 \text { mg; Cu, } 10 \mathrm{mg} \text {; CO, } 0.25 \text { mg; } \\
\text { Iodine, } 1.5 \mathrm{mg} \text {. }\end{array}$} \\
\hline
\end{tabular}


Table 2: Effect of feeding diets supplemented with raw and enzyme treated mint leaves (Mentha piperita) to broiler chicken on some serum constituents

\begin{tabular}{llllll} 
Parameters & \multicolumn{5}{c}{ Treatment groups } \\
& $\mathbf{T}_{\mathbf{1}}$ & $\mathbf{T}_{\mathbf{2}}$ & $\mathbf{T}_{\mathbf{3}}$ & $\mathbf{T}_{4}$ & $\mathbf{T}_{5}$ \\
\hline Glucose (mg/dl) & $179.47 \pm 4.41$ & $182.88 \pm 8.87$ & $176.52 \pm 12.89$ & $186.01 \pm 7.96$ & $180.89 \pm 2.35$ \\
\hline Total Protein(mg/dl) & $4.68 \pm 0.08$ & $4.73 \pm 0.09$ & $4.62 \pm 0.01$ & $4.71 \pm 0.12$ & $4.69 \pm 0.03$ \\
\hline Cholesterol (mg/dl) & $120.13 \pm 1.97$ & $118.36 \pm 3.62$ & $124.83 \pm 4.71$ & $122.16 \pm 2.98$ & $116.79 \pm 6.17$ \\
\hline SGPT (U/L) & $12.17 \pm 0.056$ & $12.74 \pm 0.91$ & $13.39 \pm 0.27$ & $13.91 \pm 1.82$ & $11.14 \pm 2.01$ \\
\hline SGOT (U/L) & $124.11 \pm 4.77$ & $127.36 \pm 8.31$ & $119.71 \pm 2.94$ & $126.94 \pm 7.76$ & $129.23 \pm 4.19$
\end{tabular}

Table 3: Carcass characteristics of broiler chicken fed diets supplemented with raw and enzyme treated mint leaves

\begin{tabular}{lccccc} 
& \multicolumn{5}{c}{ Treatment groups } \\
\multicolumn{1}{r}{ Slaughter trait } & $\mathbf{T}_{\mathbf{1}}$ & $\mathbf{T}_{\mathbf{2}}$ & $\mathbf{T}_{\mathbf{3}}$ & $\mathbf{T}_{\mathbf{4}}$ & $\mathbf{T}_{\mathbf{5}}$ \\
Feather loss (\%) & $8.25 \pm 0.60$ & $7.52 \pm 0.30$ & $7.48 \pm 0.44$ & $7.85 \pm 0.21$ & $8.41 \pm 0.47$ \\
Evisceration loss (\%) & $27.40 \pm 1.01$ & $29.42 \pm 2.27$ & $25.88 \pm 1.05$ & $26.75 \pm 0.36$ & $26.13 \pm 1.44$ \\
Giblet (\%) & $4.56 \pm 0.20$ & $4.16 \pm 0.08$ & $4.24 \pm 0.09$ & $4.51 \pm 0.16$ & $4.19 \pm 0.14$ \\
Shank (\%) & $4.84 \pm 0.16$ & $5.28 \pm 0.23$ & $4.98 \pm 0.26$ & $5.04 \pm 0.20$ & $4.78 \pm 0.25$ \\
Head (\%) & $2.84 \pm 0.06$ & $2.78 \pm 0.10$ & $2.87 \pm 0.10$ & $2.87 \pm 0.13$ & $2.83 \pm 0.13$ \\
Dressing (\%) & $69.37 \pm 1.17$ & $70.75 \pm 1.73$ & $70.53 \pm 1.32$ & $69.83 \pm 0.62$ & $70.60 \pm 1.31$
\end{tabular}

\section{Parameters Recorded}

Blood biochemistry: Blood samples from birds in different dietary groups were collected for hematological study. For this purpose 2 birds/ replicate were randomly selected for the collection of blood. Whole blood was collected from the birds in sterile test tubes, without the addition of anticoagulant and kept in slanting position. The tubes containing blood were incubated at $37^{\circ} \mathrm{C}$ for $1 \mathrm{~h}$. Blood clots were broken and tubes were centrifuged at $3000 \mathrm{rpm}$ for 30 $\min$. The serum was pipetted out in small tubes which were stored under deep freeze condition $\left(-20^{\circ} \mathrm{C}\right)$ until analysis. Serum glucose, protein, cholesterol SGPT and SGOT were estimated with the aid of auto analyzer equipment (Make: DiaSys Diagnostics India Pvt. Ltd.) by using respective biochemical kits.

Carcass characteristics: At the end of feeding trial, two birds per replicate were selected at random and utilized for carcass evaluation study. The birds were kept off fed overnight and water was withdrawn 3-4 hours prior to slaughter. The birds were weighed before fasting. The birds were slaughtered by the Halal method and a bleeding time of 2 minutes was allowed. The shanks were cut off at the hock and carcass was subjected to scalding process at $60^{\circ} \mathrm{C}$ for 30 seconds. The feathers were removed completely by hand picking leaving the skin intact. Thereafter, the abdominal cavity was opened to expose the visceral organs. Slaughter characteristics, yield of giblets and cutability characteristics were calculated by the method used by Salahuddin et al. (2000).
Sensory evaluation of meat: Sensory evaluation of meat was carried out in collaboration with Deportment of Livestock Products and Technology, Faculty of Veterinary Sciences \& Animal Husbandry, Sher-e-Kashmir University of Agricultural Sciences and Technology-Jammu, using 8-point hedonic scale for descriptive attributes of product, as described by Keeton (1983).

Preparation of meat samples: Eight breast meat samples of equal dimensions from each treatment group were taken out from the deep freezer (stored) and allowed to thaw at room temperature for two hours. The samples were washed in running tap water and fat was removed. Samples were weighed and kept in autoclave. A volume of $1.2 \%$ salt solution equal to sample weight was poured in to the autoclave. The autoclave was closed and the meat samples were cooked for $10 \mathrm{~min}$. at 15 psi pressure. The samples were removed from the autoclave and kept in bone china plates to allow them to cool to room temperature. Sensory evaluation of the samples was done by an expert panel of 10 judges on 8 point scale and judges had not taken any meal or beverages at least within one hour prior to evaluation. The samples were evaluated for general appearance, flavor, tenderness, juiciness and overall acceptability. Judging was as follows:

$\begin{array}{lllll}\text { Very good } & \text { Good } & \text { Fair } & \text { Poor } & \text { Very Poor } \\ 8-9 & 6-7 & 4-5 & 2-3 & 0-1\end{array}$


Table 4: Sensory evaluation/organoleptic parameters of broiler meat obtained from chicken fed diet supplemented with raw and enzyme treated mint leaves

\begin{tabular}{llllll} 
Attributes & \multicolumn{2}{l}{ Treatment groups } & \multicolumn{2}{l}{} \\
& $\mathbf{T}_{\mathbf{1}}$ & $\mathbf{T}_{\mathbf{2}}$ & $\mathbf{T}_{\mathbf{3}}$ & $\mathbf{T}_{4}$ & $\mathbf{T}_{5}$ \\
Appearance & $6.95 \pm .12$ & $7 \pm 0.11$ & $7.19 \pm 0.11$ & $7.09 \pm 0.11$ & $7 \pm 0.13$ \\
Flavor & $6.61 \pm 0.12$ & $6.66 \pm 0.12$ & $7 \pm 0.13$ & $6.80 \pm 0.13$ & $6.66 \pm 0.12$ \\
Juiciness & $6.66 \pm 0.12$ & $6.47 \pm 0.13$ & $6.61 \pm 0.12$ & $6.57 \pm 0.13$ & $6.52 \pm 0.13$ \\
Texture & $6.80 \pm 0.13$ & $6.90 \pm 0.13$ & $6.85 \pm 0.12$ & $6.90 \pm 0.13$ & $6.85 \pm 0.14$ \\
Mouth coat & $7.33 \pm 0.12$ & $7.42 \pm 0.11$ & $7.47 \pm 0.13$ & $7.42 \pm 0.11$ & $7.33 \pm 0.15$ \\
\hline Overall acceptability & $6.66 \pm 0.12$ & $6.76 \pm 0.11$ & $7 \pm 0.11$ & $6.76 \pm 0.11$ & $6.76 \pm 0.13$
\end{tabular}

\section{STATISTICAL ANALYSIS}

The data obtained was statistically assessed by one-way ANOVA as per the standard methods of Snecdor and Cochran (1994) using the General Linear Model Procedure of Statistical Package for the Social Sciences, Base 10.0, 1999 (SPSS Software products, Marketing Department, SPSS Inc. Chicago, USA). To test the significance of difference between means Duncan's multiple range test (Duncan, 1955) was used and differences were considered significant at $5 \%$ level.

\section{RESULTS}

\section{Blood Biochemistry}

The results of serum constituents in broiler chicken fed different dietary treatments have been summarized in $\mathrm{Ta}^{-}$ ble 2 . The serum glucose in different dietary groups varied between $179.47 \pm 4.41$ and $180.89 \pm 2.35 \mathrm{mg} / \mathrm{dl}$ with no statistical significance $(\mathrm{P}>0.05)$ among the various dietary treatments. No significant $(\mathrm{P}>0.05)$ differences in serum total protein levels were observed in the chicks fed diet supplemented with different treatment groups, the values ranging between $4.68 \pm 0.08$ and $4.69 \pm 0.03 \mathrm{mg} / \mathrm{dl}$. The serum cholesterol levels in different treatment groups varied between $120.13 \pm 1.97$ and $116.79 \pm 6.17 \mathrm{mg} / \mathrm{dl}$ with no statistical significance $(\mathrm{P}>0.05)$ among the various dietary treatments. The serum SGPT levels varied between $12.17 \pm 0.056$ and $11.14 \pm 2.01 \mathrm{U} / \mathrm{L}$ with no statistical significance $(\mathrm{P}>0.05)$ among various dietary treatments. The serum SGOT levels varied between $124.11 \pm 4.77 \mathrm{U} / \mathrm{L}$ and $129.23 \pm 4.19 \mathrm{U} / \mathrm{L}$ among the different dietary treatment groups without showing any significant $(\mathrm{P}>0.05)$ effect.

\section{Carcass Characteristics}

The results of slaughter and carcass characteristics in birds fed diets supplemented with raw and enzyme treated mint leave are presented in Table 3. The dressing percentage in broiler chicken in various experimental groups ranged between $69.37 \pm 1.17$ and $70.75 \pm 1.73$. However, this difference in dressing percentage was non-significant $(p>0.05)$.
There was no significant $(\mathrm{P}>0.05)$ difference in the yield characteristics of giblets, viz. Gizzard weight, heart weight and liver weight among different treatment groups and control group. Similarly the yield of feathers was not significant $(p>0.05)$ between various treatment groups and no significant difference was recorded in shank and head percentage among different treatment groups and control group.

\section{Sensory Attributes}

The results of sensory evaluation of the meat from different treatments are presented in Table 4. There was no significant $(\mathrm{P}<0.05)$ difference among the various sensory attributes i.e. appearance, flavour, juiciness, texture, mouth coating and the overall acceptability ranged from 6.66 to 7 .

\section{DISCUSSION}

\section{Blood Biochemistry}

The serum glucose level in different treatment groups varied between $179.47 \pm 4.41$ and $180.89 \pm 2.35 \mathrm{mg} \%$. The mean value of the glucose was found to be statistically non-significant $(p>0.05)$ among the various dietary treatment when compared with the group of birds fed control diet. Similar results were observed earlier by Al-Kassie (2009) who found non-significant difference in the blood traits among the treatment groups fed feed supplemented with Mint (Mentha piperita) when compared with the control group. The serum values of the total protein level ranged between $4.68 \pm 0.08$ and $4.69 \pm 0.03 \mathrm{~g} \%$ with no statistical significance among various dietary treatment groups and control group. However, these results are in contrast to the earlier results of (Mahboubi and Haghi, 2008) who found that leaf extracts of Mentha puleigum in rats significantly $(P>0.05)$ decreased total serum protein and albumin. However, Durrani et al. (2008) reported that supplementation of the mint in the broiler feed showed no significant $(\mathrm{P}>0.05)$ difference in albumin and protein levels, whereas, serum antibody titer for IB was found significantly $(p<0.05)$ higher for broilers fed $1.5 \%$ mint when compared to others. The serum cholesterol levels in the present study 
OPEN OACCESS

ranged between $120.13 \pm 1.97$ and $116.79 \pm 6.17 \mathrm{mg} \%$ with no statistical significance among various dietary treatment groups and control group. Similar results were recorded by Shehab et al. (2012) reported that the supplementation of enzyme in the diet of Japanese quails had no significant $(\mathrm{P}>0.05)$ effect on serum total cholesterol. However, the results of present study do not corroborate with the reports of earlier workers (Hardari et al., 2010; Aghazadeh et al., 2011; Roozbeh et al., 2013) who reported that addition of $1.5 \%$ artichoke leave meal in the diet plus $200 \mathrm{mg} / \mathrm{g}$ mentha extract in drinking water showed lowest amount of blood cholesterol in broiler chicken when compared with the group fed control diet. Similarly, Case et al. (1995) reported that $5 \%$ inhibition of $\mathrm{HMG}-\mathrm{CoA}$ reductase lowered serum cholesterol by $2 \%$ in poultry. A variety of essential oil compounds, such as menthone, menthol and geraniol have been shown to suppress the hepatic HMG-CoA reductase activity. In the present study non-significant effect on serum cholesterol level may be related perhaps to relatively low doses of mint which might have implicated in the failure of mint to reduce plasma cholesterol levels.

The serum SGPT level varied between $12.17 \pm 0.056$ and $11.14 \pm 2.01 \mu / 1$ with no statistical significance among various dietary treatment groups and control group. Similarly, the serum SGOT level varied between $124.11 \pm 4.77$ and $129.23 \pm 4.19 \mu / 1$ with no statistical significance among various dietary treatment groups and control group. It is a known fact that SGPT and SGOT are considered as liver enzymes and indicate liver damage. In the present study, no increase in serum concentration of SGPT and SGOT provides evidence that the mint leaves used had no ill effect on the health of birds. This has been earlier confirmed by A1-Jaff (2011). Likewise, no effect on SGPT and SGOT levels were observed by Qureshi et al. (2015) with other herbs like dandelion leaves and fenugreek seeds. Similar results were recorded by a number of workers (Qota et al., 2002; Shakmak, 2003; Al-Harthi, 2006) who independently found that cell-wall degrading enzymes and/or phytase supplementation had no adverse effect on biochemical constituents of plasma and liver function of broiler chicks. The variation in the results of blood parameters may be influenced by many factors including age, sex, type of bird, environmental, nutritional and physiological situation as well as purity and variation of compounds in herb and herb products as indicated by some earlier workers (Annongu et al., 2012; Tolba et al., 2010).

\section{Carcass and Slaughter Characteristics}

Supplementation of either raw or enzyme treated mint leaves supplemented diet in the broiler chicken did not reveal any significant difference $(p<0.05)$ in the carcass characteristics such as dressing percentage, yield characteristics of Giblet viz. gizzard weight, heart weight and liver weight among different treatment groups. Similarly no significant
Advances in Animal and Veterinary Sciences ( $P>0.05)$ effect in the feather percentage, head percentage and shank percentage among the different treatment groups when compared with the control group was during the entire period of study. Durrani et al. (2008) found no significant difference in gizzard weight and abdominal fat deposition among the mint supplemented groups and control groups. Khempaka et al. (2013) reported that percentage of eviscerated carcasses and giblet of broilers fed dried peppermint were similar to the control and antibiotic supplementation diet $(p>0.05)$. Amasaib et al. (2013) reported that there was no significant $(p>0.05)$ difference in dressing percentage in broiler chicken fed spearmint (Mentha spicata). Ismail et al. (2004) also reported no influence of treatment on weight of liver, proventriculus, gizzard and pancreas in broilers fed herbal plant extracts. Similarly, Toghyani et al. (2010) reported that use of peppermint had not any significant on internal organ weights. However, Narimani-Rad et al. (2011) reported that dietary supplementation of medicinal plants mixture $1 \%$ oregano, $0.5 \%$ ziziphora and $0.5 \%$ peppermint caused carcass quality improvement via more weight gain increased in carcass yield and decreased abdominal fat deposition. Likewise, Nobakht et al. $(2010 ; 2011)$ reported that a blend of Mentha pulegium with another medicinal herb significantly improved the carcass traits such as breast muscle of broilers. No effect on various carcass attributes with other herbs except for the dressing percentage has also been reported by other workers (Qureshi et al., 2016b).

\section{Sensory Evaluation}

Sensory evaluation/organoleptic evaluation of the cooked meat product from the five treatment groups in the present study revealed statistically non-significant $(\mathrm{P}>0.05)$ difference. Mint has traditionally been used as condiment and flavouring agents in cookery. Apparently there was the assumption that supplementing broilers diet with the foregoing herb might influence meat culinary properties but sensory evaluation of their meat revealed that inclusion of Mint leaves did not induce any abnormal odour or flavour in meat. This was in agreement with the observations of Toghyani et al. (2010) who reported that peppermint incorporation in broiler diet had no desirable effect on meat sensory. Similar trend was reported by Al-Sultan (2003) who reported that turmeric did not induce any abnormal flavour in the cooked broiler meat and a same finding was reported by Al-Ankari et al. (2004). Similarly, Williams and Damron (1998) reported that rendered spent hen meal had no adverse effect on the flavour of chicken meat. In contrast to the present study Dahal and Farran (2011) reported that significant mint flavour was detected in the samples chosen from the mint fed chicken. Similarly, Gbenga et al. (2009) reported a significant garlic aroma score in the meat of the chickens fed $5 \mathrm{~g}$ garlic/kg diet.

The study concluded that the dietary inclusion of raw or 
OPEN OACCESS

enzyme treated mint leaves had no negative effect on the health of birds as could be figured out from the normal SGPT and SGOT levels of birds, thus could be recommended as feed additive in broiler production.

\section{AUTHOR CONTRIBUTIONS}

All authors contributed equally in all steps of laboratory and field trials.

\section{CONFLICT OF INTEREST}

The authors have no conflict of interest to declare.

\section{ETHICAL APPROVAL}

The experimental protocol was approved by the Institutional Animal Ethics Committee

\section{REFERENCES}

-Adil S, Qureshi S, Pattoo RA (2015). A review on positive effects of fenugreek as feed additive in poultry production. Int. J. Poult. Sci. 14 (12): 664-669. https://doi.org/10.3923/ ijps.2015.664.669

- Aghazadeh R, Abdolkarimin, Ashkavand Z (2011). Effect of dietary thyme (Thymus vulgaris) and Mint (Menthe piperita) on some blood parameters of broiler chicken. J. Agric. Sci. Technol. 1288-1290.

-Al-Ankari AS, Zaki MM, Al-Sultan SI (2004). Use of Habek mint (Mentha longifolia) in Broiler Chicken Diets. Int. J. Poult. Sci. 3(10): 629-634. https://doi.org/10.3923/ ijps.2004.629.634

-A1-Harthi MA (2006). Impact of supplemental feed enzymes, condiments mixture or their combination on broiler performance, nutrients digestibility and plasma constituents. Int. J. Poult. Sci. 5(8): 764-771. https://doi.org/10.3923/ ijps.2006.764.771

-A1-Jaff FK (2011). Effect of coriander seeds as diet ingredient on blood parameters of broiler chicken raised under height ambient temperature. Int. J. Poult. Sci. 16: 82-86.

-A1-Kassie GAM (2009). Influence of two plant extracts derived from thyme and cinnamon on broiler performance. Pak. Vet. J. 29: 169-173.

-A1-Sultan SI (2003). The effect of Curcuma longa (turmeric) on overall performance of broiler chickens. Int. J. Poult. Sci. 2: 351-353.

- Amasaib EQ Abd Elrahman BH, Abdelhameed AA, Atta Elmnan BA, Mahala AG (2013). Effect of dietary levels of spearmint (Mentha spicata) on broiler chick's performance. Onl. J. Anim. Feed Res. 3(4): 193-196.

- Annongu AA, Joseph KJ Andeyina A (2010). Investigation on some biochemical and histopathological indices in broiler chickens fed detoxified Blighiasapida seed meal in diets. Afr. J. Gen. Agri. 6: 295-300.

- BIS (Bureau of Indian standards) (1992). Nutrient Requirements for poultry. IS: 13574: 1992.

- Borris RP, (1996). Natural product research: Perspective from a major pharmaceutical company. J. Ethnopharmacol. 51: 29-
Advances in Animal and Veterinary Sciences 38. https://doi.org/10.1016/0378-8741(95)01347-4

- Case L, He HM, Elson CE (1995). Induction of geranyl pyrophosphate activity by cholesterol suppressive isoperenoids. Lipids 30: 357-359. https://doi.org/10.1007/ BF02536045

- Cowan MM (1999). Plant products as antimicrobial agents. Clin. Microbiol. Rev. 12: 564-582.

-Dahal IM, Farran MT (2011). Effect of dried medicinal crops on the performance and carcass flavor of broilers. Int. J. Poult. Sci. 10(2): 152-156. https://doi.org/10.3923/ ijps.2011.152.156

- Dorman HJD, Kosar M, Kahlos K, Holm Y, Hiltunen R (2003). Antioxidant properties and composition of aqueous extracts from Mentha species, hybrids, varieties, and cultivars. J. Agric. Food Chem. 51: 4563-4569. https://doi.org/10.1021/ jf034108k

-Duncan DB (1955). Multiple range and multiple F-test. Biometrics 11: 1-42. https://doi.org/10.2307/3001478

-Durrani FR, Abidullah, Chand N, Durrani Z, Akhtar S (2008). Hematological, biochemical, immune modulatory and growth promoting effect of feed added wild mint (Mentha longifolia) in broiler chicks. Sarhad J. Agri. 24(4): 661-664.

-Durrani FR, Sultan A, Marri ML, Chand N, Durrani Z(2007). Effect of wild mint (Mentha longifolia) infusion on the overall performance of broiler chicks. Pak. J. Biol. Sci. 10(7): 1130-1133. https://doi.org/10.3923/pjbs.2007.1130.1133

- Gbenga Onibi E, Adebisi OE, Fajemisin AN, Adetunji AV (2009). Response of broiler chickens in trims of performance and meat quality of garlic (Allium sativum) supplementation. Afr. J. Agric. Res. 4: 511-517.

- Guo FC, Williams BA, Kwakkel RP,Li HS, LiXP (2004). Effects of Mushroom and herb polysaccharides as alternative for an antibiotic on the caecal microbial eco-system and broiler chickens. Poult. Sci. 83: 175-182. https://doi.org/10.1093/ ps/83.2.175

- Hardari A, Nobakht A, Safamehr A (2010). Investigation the effects using nettle (Urtica dioica), mentha pulagum (Oreganum valgare) and zizaphora (Thymus vulgaris) medicinal plants and there mixtures on biochemical and immunity parameters of broilers. Proc. $4^{\text {th }}$ Iran. Cong. Anim. Sci. 214-217.

-Hashemi SR, Davoodi H (2010). Phytogenics as new class of feed additive in poultry industry. J. Anim. Vet. Adv. 9(17): 2295-2304. https://doi.org/10.3923/javaa.2010.2295.2304

-Hussian M (2001). Geography of Jammu \& Kashmir Rajesh Publications, New Delhi, p. 28.

-Ismail M, Durrani FR, Amjad M, Suhail SM, Chand N (2004). Effect of different levels of feed added Curcuma longa on overall performance of broiler chicks. J. Agric. Biol. Sci. 1(2): 1-16.

-Jamroz DJ, Orda C, Kamel A, Wiliczkiewicz, Wertelecki T, Skorupinska J (2003). The influence of phytogenetic extracts on performance, nutrients digestibility, carcass characteristics and gut microbial status in broiler chickens. J. Anim. Feed Sci. 12: 583-596. https://doi.org/10.22358/jafs/67752/2003

•Jang IS, Ko YH, Yang HY, Ha JS, Kim JY (2004). Influence of essential oil components on growth performance and the functional activity of pancreas and small intestine broiler chickens. Asian-Australas. J. Anim. Sci. 17: 394-400. https://doi.org/10.5713/ajas.2004.394

-Keeton JT (1983). Effect of fat and sodium chloride/ phosphate level on the chemical and sensory properties of pork patties. J. Food Sci. 48: 878-881. https://doi. org/10.1111/j.1365-2621.1983.tb14921.x 
-Khempaka S, Pudpila U, Molee W (2013). Effect of dried peppermint (Mentha cordifolia) on growth performance, nutrient digestibility, carcass traits, antioxidant properties, and ammonia production in broilers. J. Appl. Poult. Res. 22: 904-912. https://doi.org/10.3382/japr.2013-00813

- Mahboubi M, Haghi G (2008). Antimicrobial activity and chemical composition of Mentha pulegium L. essential oil. J. Ethopharmacol. 19: 325-327. https://doi.org/10.1016/j. jep.2008.07.023

- Nanekarani SG, Majjid H, Nasir ML (2012). Efficiency of ethanolic extract of peppermint (Mentha piperita) as an antibiotic growth promoter substitution on performance, and carcass characteristics in broiler chickens. Asian Pac. J. Trop. Biomed. 1611-1614. https://doi.org/10.1016/S22211691(12)60462-6

- Narimani RM, Nobakht A, Shahryar HA, Lotfi AR (2011). Influence of dietary supplementation of medicinal plants mixture ziziphora, Mentha pulagum and peppermint on some serum biochemical and immunological measures of broiler chickens. J. Middle-East Sci. Res. 8: 457-459.

- Nobakht A, Shahryar HA (2010). The effects mixture of Malva silverstris, Alhaji mauroum and Mentha spicata on performance, carcass traits and blood metabolites of broilers. J. Anim. Sci. 3: 51-63.

- Nobakht A, Norani J, Safamehr A (2011). The effect of different amounts of Mentha pulegium (pennyroyal) on performance, carcass trait, hematological and blood chemical parameters of broilers. J. Med. Plant Res. 5: 3763-3768.

- Qota EMA,El-Ghamry AA,El-Mallah GM (2002). Nutritional value of soaked linseed cake in broiler diets without or with pro-nutrients or formulating diets based on available amino acids value on performance of broilers. Egypt. Poult. Sci. J. 22(4): 461- 475.

-Qureshi S., Banday MT, Adil S, Shakeel I, Munshi ZH (2015). Effect of dandelion leaves and fenugreek seeds with or without enzyme addition on performance and blood biochemistry of broiler chicken, and evaluation of their in vitro antibacterial activity Ind. J. Anim. Sci. 85(11): 12481254.

-Qureshi S, Banday MT, Adil S, Shakeel I, Mir MS, Beigh YA, Amin U (2016a). Histomorphological studies of broiler chicken fed diets supplemented with either raw or enzyme treated dandelion leaves and fenugreek seeds. Vet. World 9(3): 269-275. https://doi.org/10.14202/vetworld.2016.269-275

-Qureshi S, Banday MT, Shakeel I, Adil S (2016b). Feeding value of raw or enzyme treated dandelion and fenugreek seeds alone or in combination in meat type chicken. Pak. J. Nutr. 15(1): 9-14. https://doi.org/10.3923/pjn.2016.9.14

-Roozbeh F, Ali K, Arash A (2013). Effect of artichoke leaves meal and mentha extract (Mentha piperita) on immune cells and blood biochemical parameters of broilers. Glob. Vet.

10(1): 99-102.

-Salahuddin M, Wani SA, Pal MA, Ganaie TAS, Banday MT (2000). Carcass and meat yield characteristics of indigenous (desi) chicken in Kashmir. SKUAST J. Res. 2: 49-57.

-Shakmak S (2003). Studies on improvement of productive performance in poultry. M.Sc. Thesis submitted to Mansoura University, Egypt, pp. 1-12.

-Shehab AE, Kamelia MZ, Khedr NE, Esmaeil FA (2012). Effect of dietary enzyme supplementation on some biochemical and hematological parameters of Japanese quails. J. Anim. Sci. Adv. 2(9): 734-739.

- Snedecor GW, Cochran WG (1994). Statistical methods. $6^{\text {th }}$ edition. Iowa state university press, Ames, Iowa.

- Schuhmacher A, Reichling J, Schnitzler P (2003). Virucidal effect of peppermint oil on the enveloped herpes simplex virus type 1 and type 2 in vitro. Phytomed. 10: 504-510. https://doi.org/10.1078/094471103322331467

-Spirling LL, Daneils IR (2001).Botanical perspectives on health peppermint : more than just an after dinner mint.J. Soc. Healt, 121: 62 -63. https://doi.org/10.1177/146642400112100113

- Toghyani M, Toghyani M, Gheisari AA, Ghalamkari G, Mohammadrezaie M (2010). Growth performance, serum biochemistry, and blood hematology of broiler chicks fed different levels of black seed (Nigella sativa) and peppermint (Mentha piperita). Livest. Sci. 129: 173-178. https://doi. org/10.1016/j.livsci.2010.01.021

-Tufarelli V, Dario M, Laudadio V (2007). Effect of xylanase supplementation and particle-size on performance of guinea fowl broilers fed wheat-based diets. Int. J. Poult. Sci. 6: 302307. https://doi.org/10.3923/ijps.2007.302.307

-Yousuf S, Banday MT, Adil S (2011). Nutrient utilization of broiler chicken fed high fiber diets supplemented with enzyme and yeast. Appl. Bio. Res., 13(2): 79-83.

-Tolba A, Shabaan S, Abdel-Mageed M (2010). Effects of using Aromatic herbal extract and blended with organic acids on productive and physiological performance of poultry 2 the growth during cold winter stress. Anim. Prod. Inst. Giza 1: 229-248.

-Williams SK, Damron BL (1998). Sensory and objective characteristics of broiler meat from commercial broilers fed rendered spent hen meal. J. Poult. Sci. 77: 1441-1445. https://doi.org/10.1093/ps/77.9.1441

-Windisch W, Kroismayr A (2006). The effects of phytobiotics on the performance and gut function in monogastrics. http// en.engormix.com/ MA-Feed machinery/articles/the effect of phytobiotics-performance: 285. html.

-Yousuf S, Banday MT, Adil S, Salahuddin M, Rehman M (2012). Efficacy of enzyme and yeast supplements on performance of broiler chicken fed high fiber diets. Indian J. Anim. Sci. 82(4): 410-414. 